\title{
The Importance of Leadership Style in the University: Research Study at Universitas Islam Syekh-Yusuf Tangerang, Indonesia
}

\author{
M. Rosul Asmawi \\ Universitas IslamSyekh-Yusuf Tangerang, Indonesia
}

Doi: $10.2478 / \mathrm{mjss}-2018-0103$

\begin{abstract}
This study aims to determine the importance of a suitable leadership style in university, particularly Universitas Islam Syekh Yusuf, Tangerang City, Indonesia, considering university as an organization possesses very different culture than organizations in general. Therefore a leader should implement a suitable leadership style that complies with the members and the goals of an organization. Comprehensive and detailed data could be obtained by conducting in-depth interviews, observations, and direct involvement of the researchers. This study shows that the culture of an organization is related to the leadership style, where a strong leadership skill is needed in order to build the culture of an organization. In conclusion, the finding of this study shows that democratic leadership is an effective leadership style to be implemented in the university.
\end{abstract}

Keywords: Leadership style, leadership, organizational culture, democratic leadership, university.

\section{Introduction}

The purpose of this study is to analyze the implementation of leadership style by a leader in a university. A university as a modern organization has its own unique characteristic, different than other organizations such as business and government organizations. Therefore, adopting a suitable leadership style is an attractive option.

Assessing the leadership correlates with the leader and followers of the organization, as well as the objective to be achieved in the organization's activity and leadership style being implemented. A deep understanding of its behavior practice is needed in order to understand certain leadership style, relating to how the leader's behavior in affecting its followers to achieve the objective aligned with the desired vision. Leadership style cannot be understood at a glance, especially when it is done only by reviewing the leader's behavior without assessing and observing the background of the leaders' behavior values based on leaders' lived experiences.

Applying a suitable leadership style for a university organization is a fundamental requirement that should be understood by a leader. Since university is very different compared to the principles of the organization in general, a suitable leadership style that aligns with its followers and the objective to be achieved by the organization is needed in order to lead a university. Therefore, leadership style and the leader's ability are supporting aspects that should be improved in managing a university to compete globally.

Related to the description above, it is clear that applying leadership style not in line with the followers' response and aspired goals can cause negative impacts, such as the possibility that the university will not be able to face the global competition. University as a modern organization carries responsibility in educating and teaching the surrounding community, as well as performing research and community services. A similar opinion was expressed by Cortese (2003, in Balas, 
2008: 295) who stated that, "As modern organizations, universities have an important role for a sustainable future". Cortese's opinion (2003) was reinforced by Balas (2008:296), saying that, "Universities have the opportunity to provide their communities with graduates who have the knowledge and skills necessary to help transform their workplaces and live as responsible global citizens".

Universities have a major role to promote a higher education by producing graduated students possessing knowledge and skills required for their respective occupation. Universities around the world began to engage in activities related to sustainability and research. It is stated by Balas (2008:296), "Development of special courses on sustainability, or offering collaborative research opportunities". This theory reinforces that university must be able to build sustainability and carry out research collaboration.

University is one of the educational institutions which possess important role, especially in higher education terms. University also contributes extensively to education, teaching, research, and management as stated by Schuler (1995:199), "Its contributors cover an enormous range of experience in teaching, research, and management, in universities, polytechnics and colleges".

Every university has its own mission they want to achieve. An institution's mission is a key aspect in achieving its objectives including building the desired culture. As stated by Austin (1990:66), "In universities with a strong mission to produce knowledge, the research activities tend to be highly specialized". A powerful mission of a university creates the knowledge obtained from specialized research. Therefore innovations are required in order to produce a process of success, sustainability, and renewal of the organization, as stated by Brown and Eisenhardt (1995), "Innovation is among the essential processes for success, survival, and renewal of organizations".

Leadership style is not a stand-alone system, it related to the behavior, style, and characteristics of the leader, as confirmed by Ogbonna and Harris (2000:773):

The measure of perceived leadership style was also derived from extant literature. A review of literature pertaining to the measurement of leadership behavior, styles, and characteristics suggested that a large number of measures might possibly be appropriate (for example, Fiedler, 1967; Bowsers and Seashore, 1966).

Similarly, there are correlations among organizational culture, leadership style, and performance; as mentioned by Ogbonna and Harris (2000:771), "Interestingly, few empirical studies have combined the simultaneous examination of organizational culture, leadership style, and performance". As mentioned earlier, this study is very important in order to identify, explore, and explain the characters and relationships patterns among organizational cultures, leadership styles, and performances; therefore it is required to discover more into the matter through interviews and observations to determine the importance of leadership style in universities.

This research focuses on (1) organizational culture and (2) leadership style. Referring to Ogbonna and Harris theory mentioned above, performance is not included. Organizational culture refers to Denison and Spreitzer's opinion (1991:16) quoted from a paper presented by Comeron and Freemann, "The three aspect are: (1) culture type; (2) the congruence of cultural systems such as values, leadership style, the nature of the individual-organization bond, and strategic emphasis; and, (3) the strength of the cultures".

\section{Theoretical Background}

\subsection{Organizational Culture and Leadership Style}

A rapid technology development other dynamic changes have triggered alterations in the environment of the organization. Thus, global competition is inevitable. Regarding the above notion, Handayani (2010:127) explains:

Organizations must be able to leave behind the static policy and management practices, move to new practices in a more flexible management field. Nowadays, flexibility becomes a critical requirement for the organization because flexibility allows the organization to be more innovative 
and adaptive in responding to a rapidly changing environment.

In-depth definition of organizational culture can be found in Robbins opinion that states (1990:572):

... organizational culture refers to a system of shared meaning held by members that distinguish the organization from other organizations. This system of shared meaning is, on closer analysis, a set of key characteristics that the organization value.

Organizational culture refers to a system of shared value held by its members which distinguish one organization from the other. Shared value system is an analytical approach, a set of key characteristics of organization's value. Furthermore, Robbins (1990, in Udaya, 1994:479) argues: "Organizational culture as the dominant values are disseminated within the organization making it as the philosophy of work for the employee to be a guide for the organization's policy in managing employees and customers".

Organizational culture is essential because it is a determining factor in organizational success. A number of experts begin to agree that developing a strong organizational culture is a key to success. This success is related to performance and leadership. Building the organizational culture is not an easy task because it requires a leader with leadership characteristics.

Building organizational culture is also dependent on the applied leadership style, leadership ability, perception, behavior and collective values which are widely shared. Furthermore, building an organizational culture is determined by how to build a leader-follower relationship and a followerleader relationship to reach the goals according to the desired vision. This could be done through leaders' ability in influencing their subordinates. Mutual influences between a leader and their followers and vice-versa can be considered as leadership.

This is consistent with the opinion of Rahmani (2003:137) who states:

Changing the culture is a long and expensive process, it requires a high commitment from all of the members of the organization in order to generate profits for themselves and the organization. In order to achieve profitability, a leader should communicate the change.

Cultural building occurs because of its association with behavioral patterns of a leader showed in the leadership styles. This is consistent with the opinion of Sutarto (1991:47) stating: "The cultural change was due to the change of leadership or not at all related to leadership. A manager's leadership style is a pattern of behavior that is designed to integrate the goals of the organization with the members of the organization". The opinion was reinforced by Handoko (1989: 296) affirmed: "The leadership style is a way of how the leaders influence his or her subordinates".

A university is an educational organization possessing an organizational culture to adhere. Each university has different characteristics that distinguish it from other organizations. Regarding the organizational culture of colleges or universities, Peterson, Cameron, Jones, Mets, and Ettington, (1986, in Austin, 1990: 66) proposed that:

Key elements that contribute to a college or university's culture include mission and goals of the institution, governance structure and leadership style of administrators, curricular structure and academic standards, student and faculty characteristics, student-faculty relations, size and location, and physical environment.

One of the elements associated with university culture is the leadership style of administrators, which indicates an existing relationship between organizational culture and leadership style of administrators. Building an organizational culture cannot be done only by focusing on one aspect; instead, it is related to shared values, beliefs and norms. This was stated by Yukl \& Becker (2006:210), "Shared values, beliefs, and norms held by members of an organization are known as organizational culture. A supportive culture that values employees and their contributions facilitate empowerment".

Research on organizational culture seems to be influenced by cultural aspects, such as culture type, culture system including values, leadership styles, the bond between individual and 
organization, strategic emphasis and culture power (Denison and Spreitzer, 1991:16). The cultural aspects mentioned will be examined as one study focuses.

A cultural change cannot be implemened instantly. It takes a long time because of the human culture involvement. Concerning this matter, Michelle et al (2004) explained that: "Changing an organization's culture is not a quick fix but a multi-year process". This multi-year process requires considerable time done through research. Michelle et al.'s opinion reinforced Blair, Schuller's opinion (1995:20) which explains: "Change can be assessed over time in the context of a single institution or system, but also in relation to the wider spatial context".

Adopted organizational culture in universities relates to values, understanding and historical sense to be a code of conduct, as well as to create organized organizations (Goodenough, 1971; Moran \& Volkwein, 1992:37). Organizational culture is a pattern of basic assumptions for certain groups which have been invented, discovered, or developed in order to cope with external adaptation and internal integration problems (Schein, 1985:3; Moran \& Volkwein, 1992:37).

The above study shows that building an organizational culture correlates with the leadership style and the leader's ability. Organizational culture intended to be built is very much dependent on leadership, which involved leader's ability to implement their leadership. It will be easy for leaders possessing leadership skills to build the organization's performance. On the other hand, the incapable leader will not be able to build the desired organization.

\subsection{Understanding Leader and Leadership}

\subsubsection{Leader}

The presence of a leader is always needed by any organization including university. A leader is someone who can lead the organization to promote the desired visions. A leader is assigned to lead his or her followers (subordinates) toward the intended of shared goals. The leader has substantial duties and responsibilities, concerning the life and death of an organization. Therefore the existence of a leader should be made clear through its roles and functions.

Regarding the above matter, Hesselbein \& Cohen (1999:250) explained that:

The existence of a leader within the organization; namely the call to the function of a leader in an organization is how it should be done, why he had to perform and how to achieve success. In this aspect, the leader should be able to achieve the goals successfully. A leader must have at least one follower. (Hesselbein \& Cohen, 1999:250, in http://www.custom-essays.org, accessed May 2, 2011).

Furthermore, Hesselbein \& Cohen (1999:250) confirms, "The leader not only thinks about himself but also thinks about the sake of his followers, especially for the progress of the organization". If a leader only thinks about himself, he is not a leader but only a member of an organization. Leaders should make their existence clear. They should think about their followers. They should find ways to improve and develop the organization.

Regarding these leaders, it is confirmed by Fernandez, et al. (2010:310) that:

... Which incorporates five leadership roles essential to the success of leaders in the public sector: task-oriented leadership; relations-oriented leadership; change-oriented leadership; diversityoriented leadership; and integrity-oriented leadership.

Furthermore, Armstrong (2004:15) states: "Leadership focuses on the most important resource, people. It is the process of developing and communicating a vision for the future, motivating people and gaining their commitment and engagement".

Based on study above, it is clear that good leaders are individuals who think about and focus on human aspects, both of which include the role and attention on primary sources, namely humans. This human aspect is a central focus for a good leader. 


\subsubsection{Leadership}

Referring to literature on leadership, the author had found many theories proposed by experts. However, this study only describes the meaning of leadership relevant to the focus of the study. Armstrong (2004:139) states, "Leadership is the process of inspiring individuals to give of their best to achieve the desired result. It is about getting people to move in the right direction, gaining their commitment, and motivating them to achieve their goals".

On the other hand, a leader should be able to inspire and influence his followers, as stated by Terry (n.d, in Toha, 1983:5), "Leadership is an activity to influence peoples in reaching the target of an organization". A leader must be able to influence followers to promote vision according to the desired goals. Motivating is also part of the role that can be done by leaders, as described by Pillai, Schriesheim, \& Williams (1999), "Transformational leaders... motivate their followers to perform beyond expectations by activating followers' higher order needs, fostering a climate of trust, and inducing followers to transcend self-interest for the sake of the organization".

Based on study above, it can be stated that leadership is related to a leader's ability to motivate, inspire, and influence his followers to achieve the desired goals. This kind of leader is a good leader who considers his followers in order to meet the needs of individuals and organizations.

\subsection{Leadership style}

The leadership style of a leader is a pattern of behavior designed to integrate an organization's goals with its members' goals (Sutarto, 1991:47). Furthermore, Handoko (1989:296) states, "The leadership style is the way leaders influence subordinates". Manz \& Sims, (2010) in his book: The New Super Leadership: Leading Others to Lead Themselves, explained, "Leadership style is the pattern of behavior used by a leader in attempting to influence group member and make a decision regarding the mission, strategy, and operations of group activities". It is suggested that a leadership style is an essential concept to develop in order to understand the leader's behavioral patterns associated with the attempt to influence the complex activity of the group.

Regarding opinion above, Manz \& Sims, (2010:3) further states, "When most people think of leadership, they think of one person doing something to another person. We call this "influence" and we think of a leader as one who has the ability to influence another". This opinion confirms that leadership is related to the ability to "influence" others.

Leadership style is a "typical" behavior of a leader, as well as a discriminating factor among leaders including the ability to influence their group. Furthermore, leadership style is associated with behavioral values they believe in. A leadership style describes a deeper context of leaders' behavior which indicates values in guiding a leader's life experience. Leadership style is the way a person behaves and makes efforts to influence others.

Leadership styles cannot be understood briefly; they cannot be done only by reviewing without assessing leadership behaviors and finding out the background values that they hold dearly based on their life experiences. Mutual influences between leader-follower and follower-leader are a leadership and in turn, followers influence a leader.

\subsection{Leadership in Higher Education}

Regarding the leadership in universities, Bass (2000:22) describes, "Transformational and transactional leadership are not two ends of one dimension as Burns (1978) had posted". Thus, transformational and transactional leadership styles are referred to as two sides of the coin that cannot be separated. Regarding this matter, Bass (2000: 24-25) further confirms that:

The transactional leader addresses the material needs of the employee; the transformational leader focuses on the self-concept of the employee and the employee's sense of self-worth. The transformational leader encourages the follower to build a self-concept that identifies with the leader's self-concept and mission. Striving for consistency, the follower is motivated to exert extra 
effort to match the follower's own self-concept and mission with the perceived expectations of the leader and thereby raises his or her own sense of self-worth as a consequence. (Shamir, House \& Arthur, 1993).

Transactional leaders are considered the best, compared to other types of leaders. The reason is that transformational leaders strive to meet materials needs, encourage followers to build self-concept, create consistency, think about how to motivate his followers and turn them into new leaders.

Transformational and transactional leadership behaviors are needed in order to build the future of universities, as proposed by Bass (2000:26) stating that:

I now propose to specify what each component of the Full Range of Leadership - of transformational and transactional leadership behavior - ideally contributes to the creation and maintenance of the learning organization. The future learning organization will need such leadership at all levels of the organization.

Considering that universities have different characteristics, particularly with regard to the members of organization or followers. Therefore, a leadership style suitable for the academic field is required. Regarding this matter, Levine (2000:2) quoted Bass's opinion (1985) which argues: "Transformational leadership is the most successful form of leadership in academic settings". Furthermore, Levin (2000:2) quoted Birnbaum's opinion (1989) which confirms: "Transformational leadership is not only inappropriate for a university president but in fact renders that person less successful because of the distancing involved in becoming a truly transformational leader".

Observing the transformational leadership required in the universities, Levine (2000), citing Bass and Avolio's opinion (n.d), states: "Transformational leaders change their organization's culture by inspiring a sense of mission and purpose about the importance of the group's work and stimulating new ways of thinking and problem solving". A leader with the ability to change his intuition into a successful one is needed considering that a tight global competition in the academic field. Levine (2000), Birnbaum opinion (1992) states: "In today's world of greater participation, heeding the current call for charismatic presidents who can transform their institutions would more likely lead to campus disruption than to constructive change".

\subsection{Correlations between Leadership and Organizational Performance}

Regarding this, Ogbonna and Harris (2000:771) confirmed:

While some writers suggest that (1) the style of a leader affects performance, (2) certain types of culture are linked to superior performance, and (3) culture and leadership are related, the precise nature and form of interaction between these three concepts are not fully understood. Clearly, further research is necessary to identify, explore, and elucidate the character and pattern of association between organizational culture, leadership style, and performance.

Referring to the review above, it can be understood leadership styles correlates to the outcome of the performance, as well as the culture types concerning superior performance. Similarly, organizational culture correlates with the leadership behavior. Therefore, this research study is needed to identify, explore and explain the character and relationship patterns among the organizational cultures, leadership styles, and performances.

Implementing a suitable leadership style should adhere to the organizational culture to achieve the expected performance. In this case, it's clear that implementing the leadership style depends on the leader itself. Is he/she able to apply the appropriate leadership style that fits with the culture of the organization in order to deliver a performance? This research study should be able to answer this question.

Furthermore, the performance concerning the organizational culture that needs to be built in which the organization should be ready, capable, and willing to change as described by Bass (2000:20) who stated, "Organizations that are ready, able, and willing to change are more transformational than transactional in terms of the new paradigm of leadership (Bass, 2000)". 
Leadership and organizational culture are interrelated parts. Leadership is one of the significant and determining elements to achieve the organization's vision. This suggests that leadership is required to promote performance; including the establishment of the organizational culture in order to possess a sustainable competitiveness.

Regarding this performance, Mulyadi (1997, in Handayani, 2010:128) stated that another determining factor of organizational performance is human factor involved in the organization. Every employee has specific expectations and goals resulting in behavioral differences and performance diversities.

\section{Research Methodology}

\subsection{Research Types}

The principal aim of the study is to describe and analyze how a leadership style is implemented in a university using a qualitative approach to uncover what has occurred in the field, both factual and hidden.

\subsection{Data Collection}

In this research study, several techniques are used: (a) in-depth interview; (b) observation; and (c) documentation. Determining informants is carried out using a snowball technique. The informants were selected based on preliminary information about parties involved and determining the leadership style in the universities.

\subsection{Data Analysis}

Data analysis used a qualitative method, where collected data in the form of trimmed findings relevant to events or cases according to research focus, was presented in a narrative. Thus, the data presented are descriptive, factual and systematic. The next process is the conclusion drawing, data analysis is conducted in logical explanation, in which both data are qualitative and quantitative (secondary data) provided with complementary.

\section{Findings}

\subsection{Research Result Discussion}

Based on the interviews with the informants, organizational culture can provide encouragement and strength as well as ensuring organization's survival supported by democratic leadership style. Interview result regarding leadership style produces a transformational leadership style. According to Levine (2000) and Bass's opinion (1985), transformational leadership is the most successful form of leadership in academic settings.

This indicates that the organizational culture in higher education could be established through democratic leadership style, namely transformational leadership.

\subsection{Organizational Culture}

The organizational culture is based on Denison and Spreitzer research (1991:16) who stated that:

Three aspects of organizational cultures are: (1) culture type; (2) the congruence of cultural systems such as values, leadership style, the nature of the individual-organization bond, and strategic emphasis; and, (3) the strength of the cultures.

The study, covering three aspects of cultural value in universities, especially at the Islamic University of Syekh-Yusuf Tangerang, produced the following findings: 
The cultural power of Islamic University of Syekh-Yusuf Tangerang are cultural values including: (1) exhibiting Islamic behavior, (2) adapting noble character; (3) being honest; (4) discipline; (5) having integrity; and (6) being professional; In the older culture these cultural values were adopted by the members of the organization and are proven to be the "spirit" and strength of the organization's members in the university's academic life.

Based on these findings, it can be concluded that organizational culture could become the spirit and strength of an organization's members within a university's academic life when supported by democratic leadership style. Organizational culture at the Islamic University of Syekh-Yusuf is based on the Islamic culture and Syekh-Yusuf figure that became the institution's namesake.

\subsection{Leadership Styles}

A leadership style implemented by a leader in an organization can be observed through a leader's behavior when he or she leads the organization. It is exhibited in decision making concerning subordinates or managing the organization's culture. All of these are largely determined by the accuracy, compatibility, and appropriateness in taking an effective leadership style choice to influence the followers in order to achieve the vision in line with the desired outcomes.

Developing an organizational culture is closely related to the leadership, it is in line with the Sutarto's opinion (1991:47) confirming that "The cultural change was due to the change of leadership or not at all related to leadership. A manager's leadership style is a pattern of behavior that is designed to integrate the goals of the organization with the members of the organization". Organizational structure at the Islamic Unversity of Syekh-Yusuf could be changed into a leadership style suitable for the university' community. A suitable leadership style mentioned here is a leadership style in which a leader gives a serious thought about improving their followers and organization. This is consistent with Winston \& Patterson's opinion (2009:12) referring that "Leaders who seek their own good and not the good of the organization would be classified as "bad" leaders, whereas leaders who focus on the good of the employees and the good of the organization would be classified as "good" leaders".

Furthermore, it could be confirmed that culture is associated with leadership, as described by Ogbonna and Harrir (2000:771) who stated that "Culture and leadership are related, the precise nature and form of interaction between these three concepts is not fully understood". Effective leadership depends greatly on a leader's ability to solve problems faced by the organization, as described by Rockstuhl, et al (2011) explaining that "Effective leadership depends on the ability to solve complex technical and social problems".

Integrative leadership concept is an effective leadership model that integrates elements of transactional and transformational, situational variables (Fernandez, Cho \& Perry, 2010:310) and combines leadership skills, character, behaviour and lifestyle, as well as situational variables in a single theoretical model to explain the effectiveness of a leader (Yukl, 2002).

Based on empirical and theoretical studies above, it shows that the research findings relating to universities leadership style are a "democratic" one. Democratic leadership style is considered suitable for academic culture due to followers involvement and participation in decision-making. Armstrong (2004:115) confirmed regarding Democratic leaders, "Democratic leaders encourage people to participate and involve themselves in decision-making". Thus, it can be said that democratic leaders possessing an advantage in inviting people to participate and to be involved in the decision-making. This advantage shows that a democratic leadership is suitable to be applied in the academic setting.

Furthermore, charismatic leadership style is somewhat capable of changing the institution and is able to handle campus issues; it is as suggested by Levine (2000), citing Birnbaum's opinion (1992) that affirms: "In today's world of greater participation, heeding the current call for charismatic presidents who can transform their institutions would more likely lead to campus disruption than to constructive change".

Referring to the theory above, it is understood that the world participates more by heeding a call when charismatic presidents who are capable of revolutionizing their institutions will likely be 
able to deal with campus issues compared to constructive change. Considering that recent academic life correlates to the global competition, a leader who can transform an institution into a successful one is needed. Bass (1985, in Levine, 2000) stated, "Transformational leadership is the most successful form of leadership in academic settings".

A leadership style that is proven to be successfully implemented in an academic setting is transformational leadership. A transformational leader is capable of transforming the culture through inspiration, group work and by stimulating the thought in solving problems.

Furthermore, Bass and Avolio's (n.d) and Levine's opinion (2000) strengthen the belive that transformational leaders change their organization's culture by inspiring a sense of mission and purpose about the importance of the group's work and stimulating new ways of thinking and problem solving.

\section{Discussion}

This study was designed to analyze the importance of leadership styles suitable for organization's culture, especially in the Islamic University of Syekh Yusuf, Tangerang City, Indonesia, where the research was carried out. University as an organization has a distinct uniqueness compared to other organizations in general. Denison and Spreitzer's opinion (1991:16), quoted Comeron and Freemann's research result conducted in 334 colleges and universities, indicates that organizational culture is formed by three main aspects, namely: (1) culture type; (2) the congruence of cultural systems such as values, leadership style, the nature of the individual-organization bond, and strategic emphasis; and, (3) the strength of the cultures.

The research result on organizational culture in this institution includes: (1) Islamic culture value, and (2) Syekh-Yusuf figure after whom the Islamic University Syekh-Yusuf was named after. It has been a consensus that Islamic behavior, adopted cultural value, has become the key guidance of behaviors of the organization.

The inherent limitation of the study design is the lack of discussion with the advisory committees to analyze and interpret the research data. This research was intended to collect and interpret findings of field data using relevant theory. The researchers realize that research findings confirming the importance of democratic leadership style in a university will allow other findings in the future researchers. Conclusions drawn from this research will be more flexible if democratic leadership style becomes the conclusion of this research. Thus, it can be confirmed as a result of the research findings.

\subsection{Implication}

The implication of the findings has given institutions of higher education inputs that democratic leadership style resulted from research findings is satisfactory. However, the theory of transformational leadership style is the most effective to be implied in university management as stated by Levine (2000) citing Bass' opinion (1985) that argues: "Transformational leadership is the most successful form of leadership in academic settings". Therefore for a rector acting as a leader, transformation leadership style should be sought after in the Islamic University of Syekh-Yusuf Tanggerang.

Several limitations of this study should be made into considerations in the future research to replicate, strengthen and interpret the research data. It can be confirmed that the study's findings do not represent a definitive solution and further research is needed. The study can be specifically directed to the same or more focus.

\section{Conclusion}

In this global era where competition is getting tougher, leadership styles adopted by the university is an important factor. Therefore, an effective leadership style is required to make the organization grow and survive. It is crucial for the higher education institutions to have a leader who is capable of building the organizational culture and to provide appropriate leadership style. The research 
findings indicate that democratic leadership style is the most popular style based on the analysis of informants' opinion.

The research carried out at the Islamic University of Syekh-Yusuf Tangerang has proven that the Rector possesses a democratic leadership style. Armstrong (2004:115) explains: "Democratic leaders encourage people to participate and involve themselves in decision-making". The democratic leadership is considered to be the most suitable one for an organizational culture at universities because they encourage people to participate and get involved in the decision making.

Theoretically speaking, transformational leadership style is the most effective to manage the universities, as confirmed by Levine (2000:2) quoted Bass' opinion (1985) that argues: "Transformational leadership is the most successful form of leadership in academic settings". Concerning the research findings, a Rector possessing the leadership skills mentioned above should be sought after by higher education institutions.

Thus, the contribution of this study is to provide support for the existing theory as proposed by Levin (2000), although research result at the Islamic University Syekh-Yusuf exhibits that its Rector possessing a democratic leadership.

\section{References}

Armstrong, Michael. (2004). How to Be an Even Better Manager A Complete A-Z of Proven Techniques \& Essential Skills, Sixth Edition. Kogan, ISBN: 074944262x.

Austin, Ann E. (1990). 'Faculty Cultures, Faculty Values'. NFW Directions For Insttmonn Research, No. 68. Winicr 1990. @Joruy-Bars Inc, Publisher.

Bass, Bernard M. (2000). 'The Future of Leadership in Learning Organizations'. Journal of Leadership \& Organizational Studies, 2000; 7; 18. DOI: 10.1177/107179190000700302.

Brown \& Eisenhardt. (1995). 'Search Activities for Innovation: An Attention-Based View'. From: http://www.globethics.net. Accessed: May 9, 2011.

Denison, Daniel R., and Gretchen M. Spreitzer. (1991). 'Organizational Culture and Organizational Development: A Competing Values Approach'. Research in Organizational Change and Development. 5, 1-21. Copyright@ 1991 by JAI Press Inc. All Right of reproduction in any form reserved. ISBN:1-55938250-3.

Fernandez, S., Jik Cho, Yoo \& Perry, J.L. (2010). 'Exploring the Link Between Int Exploring the Link Between Integrated Leadership and Public'. Elsevier Inc. The Leadership Quarterly 21 (2010) 308-323. Journal homepage: www. elsevier.com/locate/leaqua.

Ferrer-Balas, D., Adachi, J., S. Banas, S., Davidson, C.I., Hoshikoshi, A., Mishra, A., Motodoa, Y., Onga, M., and Ostwald, M. (2008). 'An International Comparative Analysis of Sustainability Transformation Across Seven Universities'. International Journal of Sustainability in Higher Education. 9, 295-316. @ Emerald Group Publishing Limited, 1467-6370. DOI 10.1108/146763708 10885907 (2008).

Handayani, Agustin. (2010). 'Hubungan Kepuasan kerja dan Dukungan Sosial Dengan Persepsi Perubahan Organisasi'. Universitas Sultan Agung. INSAN. 12, Desember 2012.

Handoko, T. Hani. (1989). Manajemen. Yogyakata: BPFE.

Hesselbein \& Cohen. (1999), in http://www.custom-essays.org, accessed May 02, 2011).

Levine, Mindy Fivush. (2000). The Importance of Leadership: An Investigation of Presidential Style At Fifty National University. Dissertation Prepared for the Degree of Doctor of Philosophy, University of North Texas. August 2000.

Manz, Charles C \& Sim, Hendry P. Jr. (2010). The New SuperLeadership: Leading Others to Lead Themselves. Published by Berrett-Koehler Publishers. Copyright @ 2010 , All Rights Reserved.

Moran, T. and Volkwein, F. (1992). 'The Cultural Approach to the Formation of Organisational Climate'. Human Relations, 45, 19-47.

Ogbonna, Emmanuel and Harrir, Lloyd. (2000). 'Leadership Style, Organizational Culture and Performance: Empirical Evidence from UK Companies'. Int. J. of Human Resource Management. 11:4 August 2000 766-788.

Pillai, Rajnandini; Schriesheim, Chester A. \& Williams, Eric S. (1999). 'Fairness Perceptions and Trust as Mediators for Transformational and Transactional Leadership: A Two-Sample Study'. Journal of Management, December 1999. 25, 897-933.

Rahmani, Eny. 2003. 'Perubahan Budaya Organisasi: Suatu Alternatif Strategi Menghadapi Masa Depan'. Jurnal Bbnb dan Manajemen, 3, 127-138. Magister Sains Fakultas Ekonomi Universitas Gadjah Mada.

Robbins, Stephen P. (1990). Organization Theory: Structures, Designs, And Applications. New Jersey: Prentice Hall, Englewood Cliffs. 
Robbins, Stephen P. Terjemahan Udaya, Yusuf (1994). Teori Organisasi: Struktur, Desain, dan Applikasi. Jakarta: Arcan.

Rockstuhl, Thomas; Seiler, Stefan; Ang, Soon; Dyne, Linn Van; \& Annen, Hubert. (2011). 'Beyond General Intelligence (IQ) and Emotional Intelligence (EQ): The Role of Cultural Intelligence (CQ) on Cross-Border Leadership Effectiveness in a Globalized World'. Journal of Social Issues, 67, 825-840. Nanyang Technological University.

Schein, E. (1985). Organisational Culture and Leadership. (San Francisco: Jossey Bass).

Schuller, Tom. (1995). The Changing University. Society for Research into Higher Education, Ltd., London. ISBN-0-335-19420-6.

Shamir, Boas; House, Robert J.; and Arthur, Michael B. (1993). 'The Motivational Effects of Charismatic Leadership: A Self-Concept Based Theory'. Organization Science, 4, 577-5.

Sutarto. (1978). Kepemimpinan. Bandung: Mandar Maju.

Thomas, Moran, E. Thomas and Volkwein, J. Fredericks. (1992). 'The Culture Approach to the Formation of Organization Climate'. Human Relation, 45, 19-47.

Toha. (1983). Kepemimpinan. Bandung: Mandar Maju.

Winston, B. E., \& Patterson, K. (2009). 'An Integrative Definition of Leadership'. International Journal of Leadership Studies. 1, 6-66. @2006 School of Leadership Studies, Regent University.

Yukl, Gary A \& Becker, Wendy S. (2006). 'Effective Empowerment in Organizations'. Organization Management Journal. Linking Theory \& Practice: EAM White Papers Series, 2006. 3, 210-231. () 2006 Eastern Academy of Management. ISSN 1541-6518. 